\title{
Role of Visual Communication Design as Effective COVID-19 Information and Education Media for Community
}

\author{
N. Ilma \\ Faculty of Art and Design, Institut Seni Indonesia (ISI) Surakarta, Indonesia \\ Email: naviatulilma2001@gmail.com \\ P. A. W. Hidayat \\ Faculty of Art and Design, Institut Seni Indonesia (ISI) Surakarta, Indonesia \\ Email: putraakbarwahyuhidayat29@gmail.com

\section{Setiono} \\ Faculty of Art and Design, Institut Seni Indonesia (ISI) Surakarta, Indonesia \\ Email:dodiksetiono226@gmail.com \\ B. H. Prilosadoso \\ Faculty of Art and Design, Institut Seni Indonesia (ISI) Surakarta, Indonesia \\ Correspondence author email: basnendart@yahoo.com
}

\begin{abstract}
Visual-based technology as a medium of contact and alternative solutions in pandemic conditions requires a design role, primarily visual communication design during the coronavirus outbreak. Visual communication design becomes an intermediary bridge for information, education, and recreation media to the community. Various aspects of the design become part of applied art, which has goals and benefits to overcome problems in society. The WHO on March 11, 2020, declared the COVID-19 as a pandemic that affects almost regions of the world, where nearly more than five million people are infected. The technology eliminates distance and is an essential part of the development of visual communication design. Research on technological developments in the field of visual communication design in the application of information and education media in the spread of this pandemic. The qualitative research methods states that this research method is used well in examining the details of the research subject. The natural condition of researchers without engineering, where the research process can describe the process from time to time; $b$ ). Inductive analysis, which contains exploration orientation, discovery, and inductive logic, so that theories and patterns are in reality; and c) Description of human behaviour in its natural context.
\end{abstract}

Keywords---COVID-19, information and education, technology, visual communication design.

\section{Introduction}

Seeing the current design phenomenon is becoming very dominant and following the times. This aspect, especially in visual communication, has an essential role in facilitating the delivery of messages or information more practically. A good development if it can simplify all aspects. Design is an essential element in technology. Various designs can be used as a medium for delivering information that mediates solutions to current conditions. Visual-based technology as a medium of contact and alternative solutions in pandemic conditions requires a design role, incredibly visual communication design during the coronavirus outbreak. Visual communication design becomes a bridge between information, education and recreational media with the community. Various aspects in design are part of applied art with goals and benefits to overcome problems in society.

ISSN 2632-9409

Submitted: 9 March 2021 |Revised: 27 April 2021 | Accepted: 22 May 2021

148 
Media design, primarily visual communication design, plays an essential role because various infographic media, banners, posters, billboards, and other visual communication media can play an influential role in delivering information, publications, and education to the public. Visual communication design studies the science of delivering messages (communication) using visual or visual elements. Segmentation is critical in visual communication design so that it is right on target and effective following the character of the audience want to target. For example, posters issued by the government made with a more formal appearance. At the same time, the role of visual communication design in poster children can also be adjusted for the intended segmentation through an illustration style and layout according to the character of the intended audience.

The World Health Organization (WHO), on March 11, 2020, declared the new coronavirus disease (COVID-19) as a pandemic that affects almost regions of the world, where nearly more than five million people are infected. More than 343,000 victims in 213 countries (Health Organization World 2020), and this epidemic can change the conditions of human life on earth that are affected by the impacts (Takian et al., 2020). The spread of covid-19 has become a public health crisis which first exploded in December 2019 in Wuhan, China. It quickly spreads to more than 213 countries infecting 2.402 .350 people. The number of death recorded is 163.097 or $6.78 \%$ of the total infected cases (Mantovani et al., 2020).

Coronavirus pandemic impact will not worsen if all sectors can take advantage of it positively to respond and cope with the virus. The technology eliminates distance and is an essential part of the development of visual communication design. Layout settings, character choices, and display messages are part of education and literacy for the community. It is essential to increase legal protection in a visual identity such as a brand, considering that intellectual property rights are one of the potentials of the Indonesian State to produce goods or services that have a distinctive feature or differentiator from other countries. Often a cultural approach is also inserted in a design to facilitate the delivery of communication so that respondents can receive the message. The community role of visual communication design initiative seems to impact overcoming virus transmission positively. Anyone can participate so that this pandemic will pass quickly with a few adjustments in life afterwards to the new normal. Education on visual communication design elements must always be encouraged because the information or message to be conveyed can be wrong and cannot accept by readers or the public.

In this case, visual communication design plays a significant role as a bridge of information and education to the public, especially regarding COVID-19 and other related information. Visual communication design studies the science of delivering messages (communication) using visual or visual elements. Segmentation is essential in visual communication design so that it is right on target and effective following the character of the audience want to target. For example, posters issued by the government are made with a more formal appearance, while the role of visual communication design in poster children can also be adjusted for child segmentation through illustration styles and layouts according to children's characters. According to Miyazaki \& Dudy Wiyancoko (2006) explained that design has the meaning of a creative effort in planning and making something that has a use, by prioritizing the principle of comfort and the achievement of particular interest, it can be a system (function unity), composition (material composition), goods (used objects), products (functional objects made in the industry), artefacts (cultural objects) that made to achieve specific interests.

The community's role of visual communication design initiative seems to have a positive impact on supporting overcoming virus transmission. Anyone can participate so that this pandemic will pass quickly with a few adjustments in life afterwards to the new normal. Education on visual communication design elements must always be encouraged because the information or message to be conveyed can be wrong and cannot accept by readers or the public. So in this study will describe why the importance of visual communication design, which has advantages in all aspects, both visual, soundly, material, and messages that the general public can accept (Heriwati et al., 2020; Suwandana, 2019).

\section{Research Methods}

Research on technological developments in the field of visual communication design in the application of information and education media in the spread of this pandemic. According to Turan (2014), the explanation of qualitative research methods states that this research method is used well in examining the details of the research subject (Prilosadoso et al., 2020). In various literature, the notion of qualitative descriptive research, as Sutopo (2003) stated, will have several reasons, such as a). The natural condition of researchers without engineering, where the research process can describe the process from time to time; b). Inductive analysis, which contains exploration orientation, discovery, and inductive logic, so that theories and patterns are in reality; and c) Description of human behaviour in its natural context (Nugrahani, 2012; Pressgrove et al., 2018; Houts et al., 2006). 
The data analysis technique uses data collection stages, data reduction, data presentation, and concluding. Design always attaches importance to tools for processing (data/information), subjects that are in the processing (problem) and processing (designer) stage. This study uses a design thinking method that adapts from some literature that goes through a development process according to the conditions and needs. This study uses a design thinking method that adapts from some literature that goes through a development process according to the conditions and needs.

A qualitative research approach like this can trace back to the explanation by McLean \& Campbell (2003) that in the researcher's activities it is left to his apparatus in the task of weighing the consequences that will be caused by one or more sampling methods in research, knowing that sampling is an inseparable unity. Part of a series research, which can undoubtedly "make or break" analysis (Noy \& Noy, 2008; Killen \& Kjaer, 2012; Nickel et al., 2020). The design research flow is developed simply by using research methods and analytical methods. The research method by looking at the design phenomenon in various media today, including social media. Media analysis by comparing theories by other researchers. After finding the problem to be studied, the research continues through data collection, literature review, analysis, and then an evaluation after the data is collected, classified, and analyzed as the last step in this literature study. The data analysis technique uses data collection stages, data reduction, data presentation, and concluding. For this research, the data validation process carried through technical triangulation, triangulation of data sources and theory triangulation to facilitate the process and analysis results to be more valid (Prilosadoso et al., 2019; Crilly et al., 2004; Ord et al., 2002).

\section{Results and Discussions}

\section{Development of visual communication design as media in COVID-19}

Process and communication technology have contributed to the general process of commodification in design. The process of commodification that works in society as a whole enters communication and institutions so that improvements and contradictions in social commodification affect communication as a social practice. The progress of developments in the field of technology and information has made possible a combination of verbal presentations, namely: various narratives and text on the monitor screen with nonverbal presentation modes, namely graphics, animation, video, and sound, all of which are in one device in the form of a computer, gadget or device other. (Moreno \& Mayer, 1999; Zhang, 2012; Perry \& Sanderson, 1998).

The technology eliminates distance and is an essential part of the development of visual communication design. Social media has developed into a platform that shows prestige for its users. The designers disseminate their work using social media such as Instagram, YouTube, Pinterest, Dribble, and many more. They usually also share their design knowledge on the platform but not plagiarize their work. All these conveniences are, of course, for the benefit of many parties, not only from design students academically but also those who do not have any background knowledge to learn from this platform.

Talking about visual communication design is not far from advertising. Advertising, which is the use of mixed media by sellers to communicate persuasive information about products, services, or organizations, is a powerful promotional tool. The role of advertising in marketing a product is to build awareness of the product, increase consumer knowledge about the product, persuade potential consumers to buy and use the product.

All elements of society can use visual communication design as a medium for initiative and expression in this pandemic outbreak. Education is needed regarding visual communication design so that the information or message to be conveyed is right on target or is not accepted by the audience. Learning at this time is obtained from the formal sector and facilitated by the existence of YouTube, Instagram, and online platform applications. Applications play an important role in achieving effective learning if used properly and correctly. Let us together instil the spirit to adapt, continue with life, and carry out a "new normal" so that we can come back out with some adjustments according to health protocols. This is done because life must continue, and humans cannot always isolate themselves. If this is done forever, the economy will collapse, the industry will not work, people will lose income, and there will be chaos. Therefore, people must begin to get used to living as usual side by side with the coronavirus but still adhere to health protocols that must be adhered to, such as increasing interactions via online, digital payments, maintaining distance, and avoiding crowds. The science of visual communication design, in this case, plays an essential role in the effectiveness of the media for disseminating information and is implicit in technological developments. So that education on learning visual communication designs is essential to deal with the development of coronavirus transmission. Collaboration is between media and appropriate communication in delivering material, especially media, especially related to visual communication design related to tools that carry messages between the communicator or publisher and the communicant or user community. To be able to evaluate the effectiveness of 
various communication media, several dimensions are needed (Prilosadoso et al., 2019; Nicholson-Cole, 2005; Vigoroso et al., 2020).

\section{Conclusion}

The development of technology in the era of the millennial generation is increasingly rapid and penetrates the world of design. A design, especially a visual communication design, makes it easier to convey information through a sign. These issues can be related to various disciplines, including semiotics (sign symbolism), linguistics (language), communication, psychology, anthropology, history, ethics, and philosophy. The design is made not only aesthetically pleasing but also has a valuable function. It is believed that the impact of the coronavirus pandemic will provide benefits if all sectors can be used positively to respond. The technology eliminates distance and is an essential part of the development of visual communication design. Layout settings, character choices, and display messages are part of education and literacy for the community.

\section{Acknowledgments}

Our writing team would like to thank the Indonesian Institute of the Arts (ISI) Surakarta, especially the Visual Communication Design Study Program, the Faculty of Art and Design for supporting the preparation of this article which, of course, there are still many improvements and inputs needed to be more successful.

\section{References}

Crilly, N., Moultrie, J., \& Clarkson, P. J. (2004). Seeing things: consumer response to the visual domain in product design. Design studies, 25(6), 547-577. https://doi.org/10.1016/j.destud.2004.03.001

Houts, P. S., Doak, C. C., Doak, L. G., \& Loscalzo, M. J. (2006). The role of pictures in improving health communication: a review of research on attention, comprehension, recall, and adherence. Patient education and counseling, 61(2), 173-190. https://doi.org/10.1016/j.pec.2005.05.004

Heriwati, S. H., Pujiono, B., Panindias, A. N., \& Prilosadoso, B. H. (2020). Hanoman 's 2D Animated Character in Ramayana Wayang Story. International Journal of Social Sciences and Humanities (IJSSH), 4(3), 168-174. https://doi.org/10.29332/ijssh.v4n3.527

Killen, C. P., \& Kjaer, C. (2012). Understanding project interdependencies: The role of visual representation, culture and process. International Journal of Project Management, 30(5), 554-566. https://doi.org/10.1016/j.ijproman.2012.01.018

Mantovani, A., Dalbeni, A., \& Beatrice, G. (2020). Coronavirus disease 2019 (COVID-19): we don't leave women alone. International Journal of Public Health, 65(3), 235-236. https://doi.org/10.1007/s00038-020-01369-4

Nicholson-Cole, S. A. (2005). Representing climate change futures: a critique on the use of images for visual communication. Computers, environment and urban systems, 29(3), 255-273. https://doi.org/10.1016/j.compenvurbsys.2004.05.002

Nickel, K., Orth, U. R., \& Kumar, M. (2020). Designing for the genders: The role of visual harmony. International Journal of Research in Marketing, 37(4), 697-713. https://doi.org/10.1016/j.jiresmar.2020.02.006

Moreno, R., \& Mayer, R. E. (1999). Cognitive Principles of Multimedia Learning: The Role of Modality and Contiguity. Journal of Educational Psychology, 91(2), 358-368. https://doi.org/10.1037/0022-0663.91.2.358

Noy, C., \& Noy, C. (2008). Sampling Knowledge: The Hermeneutics of Snowball Sampling in Qualitative Research. International Journal Social Research Methodology, 11(4), 37-41. https://doi.org/10.1080/13645570701401305

Nugrahani, F. (2012). Dolanan Jawa Dalam Rangka Pembentukan Karakter Bangsa (Kajian Semiotik). Kajian Linguistik Dan Sastra, 24(1), 58-68.

Ord, T. J., Peters, R. A., Evans, C. S., \& Taylor, A. J. (2002). Digital video playback and visual communication in lizards. Animal Behaviour, 63(5), 879-890. https://doi.org/10.1006/anbe.2001.1983

Perry, M., \& Sanderson, D. (1998). Coordinating joint design work: the role of communication and artefacts. Design studies, 19(3), 273-288. https://doi.org/10.1016/S0142-694X(98)00008-8

Pressgrove, G., Janoske, M., \& Haught, M. J. (2018). Editors' letter: New research and opportunities in public relations and visual communication. Public Relations Review, 44(3), 317-320. https://doi.org/10.1016/j.pubrev.2018.04.006

Prilosadoso, B. H., Pujiono, B., \& Supeni, S. (2020). The Character of the Pacitan Wayang Beber Cartoon as a Cultural Preservation Effortfor Millennial's Generation. International Journal of Advanced Science and 
Technology, 29(4), 2517-2522 http://sersc.org/journals/index.php/IJAST/article/view/21090

Prilosadoso B H, B Pujiono, S Supeni, B. W. S. (2019). Wayang Beber Animation Media as An Effort for Preserving Wayang Tradition Based on Information and Technology. International Conference Computer Science and Engineering (IC2SE), Journal of Physics: Conference Series PAPER, 1-5. https://doi.org/10.1088/1742$6596 / 1339 / 1 / 012109$

Suwandana, I. G. M. (2019). Role of transformational leadership mediation: effect of emotional and communication intelligence towards teamwork effectiveness. International research journal of management, IT and social sciences, 6(2), 52-62.

Vigoroso, L., Caffaro, F., \& Cavallo, E. (2020). Occupational safety and visual communication: User-centred design of safety training material for migrant farmworkers in Italy. Safety science, 121, 562-572. https://doi.org/10.1016/j.ssci.2018.10.029

Zhang, K. (2012). Using visual languages in management. Journal of Visual Languages \& Computing, 23(6), 340343. https://doi.org/10.1016/j.jvlc.2012.09.001

Takian, A., Kiani, M. M., \& Khanjankhani, K. (2020). COVID-19 and the need to prioritize health equity and social determinants of health. International Journal of Public Health, 65(5), 521-523. https://doi.org/10.1007/s00038-020-01398-z 